\title{
Resurrections before the Resurrection in the Imaginaire of Late Antiquity ${ }^{1}$
}

\author{
DANUTA SHANZER \\ Universität Wien, Österreichische Akademie der Wissenschaften \\ e-mail: danuta.shanzer@univie.ac.at \\ ORCID: 0000-0002-9078-8086
}

\begin{abstract}
This paper is a study of transformations and mutations of a natural human desire, to be buried in one grave with one's beloved. Most partners don't die simultaneously, and burial-practices needed to provide flexibility for the dead and for the living. At the same time, religions had Views about the grave and the afterlife, and about the survival of the individual. Judaism and especially Christianity featured an astonishing doctrine, the Resurrection of the Flesh. Starting from Roman antiquity and in its epitaphic practices, the paper analyzes an intriguing early 4th C. Gallic poem, the Carmen de Laudibus Domini and its account of how the corpse of a dead woman was momentarily reanimated to greet her husband's corpse. The poem reworks the resurrection of Lazarus with a little help from Juvencus. But a crucial (and underworked) source is (perhaps indirectly) Tertullian's De Anima. These texts somehow generated a Late Antique urban legend about the mini-Resurrections of lovers' bodies than can be traced into the central Middle Ages and beyond. It proved astonishingly lively and adaptable - to mariages blancs, to homosocial monastic situations, and to grave robbery, to name a few. This deeply sentimental legend needed to elbow aside darker phenomena, charnel (and also erotic) horrors from the pagan past, including zombies, vampires, and revenants, in order to preach its Christian message and help lovers who had been separated by death. Such resurrections were a down-payments on The Resurrection.
\end{abstract}

KEYwords: Love, death, burial à deux, virginal marriage, resurrection (temporary), Late Latin poetry, Gregory of Tours, urban legends, revenants

Suscipe me sociam tumulis dulcissime coniunx

Cum mors est tecum non meruisse mori. ${ }^{2}$

1 My heartfelt thanks to the kind friends and colleagues who help answer my questions about material culture: Barbara Borg, first and foremost. Also to Florin Curta, Ortolf Harl, Paul Van Ossel, Patrick Périn, Renate Pillinger, Bailey Young. And special gratitude to Kurt Smolak who with his characteristic sharp eyes, Sprachgefühl, and generosity corrected my German translation in an (oral) German version! Warm thanks to Pt. Marcin Kowalski and the Team at the KUL for their kind invitation to a wonderful conference and to The Biblical Annals' anonymous referee for helpful feedback.

2 E. Diehl, Inscriptiones latinae christianae veteres (Berlin: Weidmann 1925) I, no. 205. 


\section{Grave Affairs: "When one of us dies, I want us to be buried in the same grave..."}

Carpe diem! Enjoy the day, for tomorrow you must die! The $17^{\text {th }} \mathrm{C}$. English poet Andrew Marvell memorably imagined his coy mistress' tomb and her physical virginity devoured by worms, urging her to make love with him, with the following argument: "The grave's a fine and private place, but none, I think, do there embrace..." A prudent qualification for in Antiquity, some were indeed depicted embracing there as in the magnificent sarcophaguses of Ramtha Visnai and Thanchvil Tarnai from the Ponto Rotto Necropolis in Vulci in the Museum of Fine Arts, Boston. ${ }^{3}$ And ancient double burials of men and women have been excavated, such as the $5^{\text {th }} \mathrm{C} . \mathrm{CE}$, "Lovers of Modena." ${ }^{4}$ The epitaph cited beneath the title documents the natural human instinct to want to lie next to one's partner. ${ }^{5}$ In this paper I'll start from the concept of Burial with One's Beloved, and pursue its reception during a period when a major eschatological innovation was taking place. With the advent of Christianity, a new doctrine, the Resurrection of the Body, gained momentum. How did Later Roman writers use joint burial and Resurrection to "think with"? How did this touching scenario manifest itself in textual artifacts?

\subsection{No General Resurrection}

First a few broad brush-strokes on the underlying canvas. Pagans did not believe in any general Resurrection at the end of days. ${ }^{6}$ One's body decomposed on earth, while one's soul was either tortured in the underworld or blissful in heaven.

3 S. Haynes, Etruscan Civilization: A Cultural History (Los Angeles, CA: J. Paul Getty Museum 2000) 287-291 who says (291) that they are elsewhere unparalleled except at Chiusi, fig. 240. These are graves of the Tetnie family. Angelo Brelich (Aspetti della morte nelle iscrizioni sepolcrali dell'impero romano [Dissertationes Pannonicae 1/7; Budapest: Istituto di Numismatica e di Archeologia dell' Università Pietro Pázmány 1937] 18) notes the extreme polarities in Etruscan sepulchral imagery.

4 http://www.dailymail.co.uk/news/article-2057415/Together-forever--lovers-holding-hands1-500-years-discovered-Rome-grave.html [access: 3.10.2019]

5 Ancient epitaphs exploited a word-play on tumulus and thalamus, for which see CIL 2.3001 servandus nunc est / pro thalamo tumulus; AE 1960.97 hoc sita / nunc tumulo ra/pta viri thalamo; CIL 6.25427 quos iungit tumulus iunxerat ut thalamus; CLE 670, 1399, 1432, ICUR 7.18944 and CLE 1355.

6 See in general: N.T. Wright, The Resurrection of the Son of God (Minneapolis, MN: Fortress Press 2003) 32-35 and G.W. Bowersock, Fiction as History: Nero to Julian (Berkeley, CA - Los Angeles, CA - London: University of California Press 1994) 102. Christian forgers tried to make their Sibyl prophesy the Resurrection. See Or. Sib. 4.179-85. See also R. MacMullen, Paganism in the Roman Empire (New Haven, CT - London: Yale University Press 1981). At 33-57 he discusses the inadequacies of the pagan afterlives (to some extent) and insists that they don't really promise immortality. At 55 he asks whether it is fair to believe that belief in a resurrected god entails personal resurrection, and finds no support for the assumption. Christianity really was different. 
Heaven and hell were located in different places at different periods. The dead were also often seen as somehow living in their tombs and were remembered and refreshed there. ${ }^{7}$ Ghosts were part of this ancient world.

\subsection{Individuals Who Come Back to Life}

But what about classical phenomena that seem similar to Resurrection? There were myths about miraculous returns from Hades (Eurydice, Alcestis, Protesilaos), where love conquered death. ${ }^{8}$ There was also one famous Hellenistic tale of an erotic visitation, a dead maiden, Philinnion, who came to visit a youth she had fallen in love with, to have sex with him. She was discovered ultimately to be a walking corpse, not a dream-vision or a disembodied spirit. ${ }^{9}$ The tale ended tragically. Its modern adaptation is famous - Goethe's "Braut von Corinth." In English such entities are called "revenants." They will either die a second time or are not truly alive. Bram Stoker, the author of Dracula, christened them "the Undead." And like vampires they needed to rest in their graves during the daytime. ${ }^{10}$ Needless to say, traditions about vampires almost always have erotic overtones.

\subsection{Resurrection}

But what happens when a major change in eschatological expectations occurs? ${ }^{11}$ When one can reckon with being raised in the flesh at End Time? Consider legal questions, e.g. How would a general Resurrection affect one's marital life in he-

7 A.D. Nock, „Cremation and Burial in the Roman Empire,” HTR 25/4 (1932) 332-333; a nice example in K. Hopkins, Death and Renewal: Sociological Studies in Roman History (Cambridge: Cambridge University Press 1983) II, 247-248. Also R. MacMullen, Christianity and Paganism in the Fourth to Eighth Centuries (New Haven, CT - London: Yale University Press 1997), 111 and E.-J. Graham, „Corporeal Concerns: The Role of the Body in the Transformation of Roman Mortuary Practices," Death Embodied Archaeological Approaches to the Treatment of the Corpse (eds. Z.L. Devlin - E.J. Graham) (SFA 9; Havertown, PA: Oxbow Books 2015), 32 for tombs with libation pipes for wine. See now R. MacMullen, „Roman Religion: The Best Attested Practice,” His 66/1 (2017) 111-127 for scholarly neglect of what MacMullen calls Roman ancestor-worship.

$8 \quad$ For more examples, see Wright, The Resurrection, 64-65.

9 J. Doroszewska, The Monstrous World: Corporeal Discourses in Phlegon of Tralles 'Mirabilia (Warsaw Studies in Classical Literature and Culture 4; Frankfurt am Main: Peter Lang 2016) 25 rightly emphasizes the distinction.

10 Pseudo-Quintilian, DMaiores 30, (sepulchrum incantatum, "the magicked tomb,") an intriguing witness to Late Antique conceptualizations of such phenomena, has been neglected in the literature. I hope to treat this fascinating text separately in another context.

11 Alfred Stuiber (Refrigerium interim. Die Vorstellungen vom Zwischenzustand und die frühchristliche Grabeskunst. XI. Theophaneia [Bonn: Hanstein 1957] 16) notes how sharply the Resurrection divided pagan and Christian eschatological thinking. 
aven? Sadducees, who didn't believe in Resurrection, had set Jesus a puzzler in Mt. 22.23-28 about the afterlife. To whom would a woman belong who had been married successively to seven brothers in accordance with the levirate system? Jesus cut the Gordian Knot: "In the resurrection they neither marry, nor are given in marriage, but are as the angels of God in heaven." 12

\subsection{Christian Dead and Place}

And what about place and resting place? Unlike pagan cults and unlike Judaism, Christianity should have been "atopian," a system where burial itself, let alone burial-place were irrelevant. Paganism required last rites and burial for safe passage to the afterworld. In Christianity, which started as a missionary religion to be practiced anywhere, all places were potentially equal, nor should the fact of or nature of one's burial have made any difference. ${ }^{13}$ But this is not how things turned out. Christians eventually buried their dead together, inhumated, in holy places, near saints. Augustine discussed the theological problems related to burial in his famous tractate "On the Care of the Dead" of 429. And pilgrimage would be institutionalized by the later 4 th $\mathrm{C} .{ }^{14}$

\subsection{Corpses}

And what about attitudes to the bodies of the dead? Corpses were polluting for pagans $^{15}$ and also for Jews. ${ }^{16}$ But not for Christians. Mainstream Christianity would eventually institute a cult of relics that could look a great deal like worship

12 Tertullian, Ad uxorem 1.1.4 promises nulla restitutio nuptiarum in diem resurrectionis and 1.1.5 assures the woman married to seven brothers that none will be waiting on the other side to cause her confusion and distress; at 1.1.6 he assures his wife that he isn't recommending perpetual widowhood out of anxious or jealous concerns about eventual marital relations in heaven.

13 Tert. Anim. 51-58. Contrast pagan views about ataphoi.

14 B. Kötting, Peregrinatio religiosa: Wallfahrten in der Antike und das Pilgerwesen in der alten Kirche (Münster: Regensberg 1950). I am grateful to Friederike Hassauer for showing me an attack on pilgrimage to Compostela by Martin Luther. See F. Hassauer, Santiago: Schrift, Körper, Raum, Reise. Eine medienhistorische Rekonstruktion (München: Fink 1993) 245: Luther felt one didn’t know whether Saint James rested there_-or a dead dog.

15 Not however the burial places themselves once the corpse had been properly interred or cremated. For what he calls "Roman ancestor-worship" including a very useful epigraphical appendix, see R. MacMullen, „The End of Ancestor Worship: Affect and Class,” His 63 (2014) 487-513. On heroes (and saints), see J.N. Bremmer, „From Heroes to Saints and from Martyrological to Hagiographical Discourse," Sakralität und Heldentum (eds. F. Heinzer - J. Leonhard - R. von den Hoff) (Würzburg: Ergon 2017) 35-66.

16 See Holger Michael Zellentin (Rabbinic Parodies of Jewish and Christian Literature [TSAJ 139; Tübingen: Mohr Siebeck 2011] 191-192) who, however, notes that Cynics were an exception. 
of the criminal dead to hostile beholders. ${ }^{17}$ And Christians needed to become more and more familiar with the dead and their graves. They eventually brought the graves of their "very special dead" 18 not just into the city, but into its religious center, the urban church.

\subsection{Funeral Planning}

And what of funeral planning? Roman epitaphic practice helpfully left open the possibility of planning for a Hereafter with a partner of one's choice. ${ }^{19}$ We have one extraordinary example from Vasto, where a double sarcophagus contained genealogies of two married cousins - on the inside. ${ }^{20}$ One could also cite an amusing modern continuity: Leonard Mosley related the following of Lord Curzon, Viceroy of India (1859-1925) and his two wives, Mary and Grace:

When the service was over, his body was put aboard the train and taken north to his beloved Kedleston. There, in the beautiful little Memorial Chapel which he had built, he was laid beside his beloved first wife, Mary, underneath the marble figure of the adoring Angel. And though the last years of his life had not been exactly filled with mirth, he did, in death, have his one little joke. Some months after his interment, Grace visited his tomb to leave some flowers. The electric light failed and she fumbled around among the shelves on which lay the remains of the $\mathrm{Cu}-$

17 Pagans, like Eunapius: Consider his remarks about the martyrs in Vitae Sophistarum 6.11.6-7 Giangrande. Or "proto-Protestant" figures like Vigilantius, preserved in Jerome's CVigilantium. See MacMullen, Christianity and Paganism, 115 for Faustus the Manichee.

18 To use Peter Brown's now viral expression from P. Brown, The Cult of the Saints: Its Rise and Function in Latin Christianity (Chicago: University of Chicago Press 1981) 69.

19 J.E. Sandys, Latin Epigraphy: An Introduction to the Study of Latin Inscriptions (Cambridge: Cambridge University Press 1919) 61-62 on the uses of "V" and " $\theta$." The joke (which I heard from Roger Tomlin) is one of "Beachcomber's" who in the "By the Way" column in the Daily Express once advertised an ocean cruise (a competition prize?) that included "free burial at sea with partner of one's choice.' Ch. Pietri (, Grabinschrift II (lateinisch)”, RAC XII, 577) says that bisomus and biscandens (IUR NS 8159 v. J. 393) are the terms for a grave for two people. The former is a hapax in Theodora's inscription in ICUR I. 317 (Supplement 1703): Theodora quae vixit annos XXI m. VII d. XXIII in pace est bisomu. For a later $5^{\text {th }}$ C. Gallic example, see E.F. Le Blant, Inscriptions chrétiennes de la Gaule antérieures au VIIIe siècle (Paris: L'Imprimerie Impériale 1856) II, 30-31: Ampelius died in 472, his wife Singenia in 496. She toughed out 20 years of castitas perpetua after his demise. For a sequence of bisomus and biscandens tituli, see E. Diehl, Inscriptiones latinae christianae veteres (Berlin: Weidmann 1927) II, 279-284: not all were for married couples, but most were, e.g. 3798B, 3801, 3802, 3802A, 3804, 3807 etc.

20 ILS 915, discussed by H. Brandenburg, ,Der Beginn der stadtrömischen Sarkophagproduktion der Kaiserzeit,” JdI 93 (1978) 280-283 and M. Corbier, „Constructing Kinship in Rome: Marriage and Divorce, Filiation and Adoption," The Family in Italy: from Antiquity to the Present (eds. D.I. Kertzer - R.P. Saller) (New Haven, CT: Yale University Press 1991) 138. 
rzon ancestors. Her fingers encountered, on one of them, a slip of paper. When the lights went on again, she read it: 'Reserved for the Second Lady Curzon,' it said, in Curzon's handwriting. ${ }^{21}$

\subsection{Both at Different Times}

Few couples could successfully pray to die at the same moment like Philemon and Baucis, ${ }^{22}$ and few entombed themselves live with their spouses. ${ }^{23}$ And virtuous Christians should marry only once. How did this affect their thinking about death and burial? And what does any of this have to do with Resurrection? I'll be exploring these questions by careful readings of an interesting sequence of inter-related stories, ranging from the New Testament down to $6^{\text {th }}$ and $7^{\text {th }}$ C. Gaul and Byzantium.

\section{De laudibus}

We'll start in early $4^{\text {th }} \mathrm{C}$. Gaul, where a text known as the Carmen de laudibus domini, contains what has been considered the first description of a post-Biblical miracle from the ancient world and is the earliest reasonably securely datable (post-316/17) Christian poem in Latin. ${ }^{24}$ This eccentric item is concerned with resurrection, both being resurrected and resurrecting. I'll summarize its story.

\subsection{The Miracle in De laudibus}

A loving Christian husband and wife from Gaul each hoped to predecease the other, but the woman died first. ${ }^{25}$ The bereft widower caused a large tomb to be made to accommodate both his wife and eventually himself, for in life they had slept in one bed. And when he died, the woman's corpse, though bound tight in

21 L.O. Mosley, Curzon: The End of an Epoch (London: Longmans 1960) 269.

22 Ovid, Met. 8.708 et quoniam concordes egimus annos/auferat hora duos eadem, nec coniugis umquam/busta meae videam neu sim tumulandus ab illa.

23 As did the notorious Widow of Ephesus in Petronius, Sat. 111-112.

24 For its early fortuna in literary histories, see W. Brandes, Über das frühchristliche Gedicht »Laudes Domini«: Nebst einem Excurse: Die Zerstörung von Autun unter Claudius II (Braunschweig: Meyer 1887) 18.

25 De laudibus 10-14, 
grave bandages, was caught stretching out her left hand ${ }^{26}$ to her husband with a gesture of living love. The poet asks himself who granted feelings to the dead, who released the bonds, how did the dead woman see her husband's shade coming? The answer is, of course, that it's a miracle of Christ's, whose continuing revelation teaches us that sleeping limbs rise.

Tunc desolatus largo iubet ore cavari, (15)

post mortem fiant quae membris hospita saxa:

$\uparrow$ susciperet veniens, aeternaque foedera iungens;

ut, quos viventes tenuisset lectulus idem,

post praecepta Dei, bustum commune levaret.

Sensit vota sui coniunx praesaga mariti, (20)

magnaque temporibus tribuit miracula castis:

nam cum defunctis iungantur brachia membris,

et repetita manus constringant vincula trunco,

ne, quibus humanae complentur munera vitae,

accidat informis fluitatio dissociatis. (25)

Immensum dictu! Quo tempore vita peracta est,

iungendus sociae prospecta sede maritus,

postquam morte viri reserata est ianua leti,

horrendumque larem iam lux ingrata retexit:

Deprensa est laevam protendens femina palmam, (30)

Invitans socium gestu viventis amoris.

Quis dedit affectum tumulo? Quis vincula solvit?

Unde sepulta videt venturi conjugis umbram?

$\mathrm{Tu}$ facis haec, tu Christe Deus, tua signa moventur

paulatimque doces sopita resurgere membra $(35)^{27}$

"The grief-stricken [husband] then ordered a rock-tomb to be excavated with a wide entrance to host [their] limbs after death, so that those whom one and the same marital bed had held when alive, after the commands of the Lord, ${ }^{28}$ a shared grave should gently cover. The wife had a presentiment of her husband's

26 For this as a supposedly authentically Gallic superstition, see I. Opelt, „Das Carmen de laudibus Domini als Zeugnis des Christentums bei den Galliern," RomBarb 3 (1978) 163 who cites Pliny, NH 28.25: Alius saliva post aurem digito relata sollicitudinem animi propitiat. pollices, cum faveamus, premere etiam proverbio iubemur. In adorando dextram ad osculum referimus totumque corpus circumagimus, quod in laevum fecisse Galliae religiosius credunt. Fulgetras popsymis adorare consensus gentium est. In Pliny the Gauls consider right to left a more auspicious direction.

27 Text of A. Salzano, Laudes Domini: Introduzione, testo, traduzione e commento (QDSA USS 23; Napoli: Arte Tipografica 2000) 33-34 with some adjustments of capitalization.

28 This presumably refers to the Lord's commands about monogamous marriage, e.g. Gen. 2.24, Mt. 19.5 
longing commitment and contributed a great miracle to these times of chastity: for, although the arms of the dead are joined to their limbs, and multiple bonds bind the hands tightly to the trunk, lest a repulsive dissolution befall those whose task in life was fulfilled once [their limbs] have fallen apart ${ }^{29}$ —astounding to relate! - when, [the course of] his life was over, after upon the demise of the husband, the door of death had been opened, and the now unwelcome daylight had disclosed the fearsome abode, the woman was caught stretching out her left hand, inviting her husband with a gesture of living love. Who granted feeling to [the one in the] tomb? Who undid the bonds? From where did the buried woman see her husband's shadow coming? You accomplish these things, you Christ, God, your signs are set in motion and you gradually ${ }^{30}$ teach that limbs that sleep rise." (Trans. DRS)

\subsection{Models: Classical and Christian}

To understand this miracle, one must examine sources and models. There are plenty of pagan parallels for themes such as one grave, chastity of the survivor, praying to die simultaneously. ${ }^{31}$ But no one has explored the Christian primary sources adequately. ${ }^{32}$ Textual detectives look for clues, significant anomalies that can be traced, like DNA, to their sources. And there are several oddities in the passage. The first are archaeological and directly concerned with realia. 1 . The rock tomb. 2. The mummy-like bandaging of the corpse. All of the archaeologists I have consulted assure me, as I had suspected, that people were not buried in caves excavated in the rock in Late Antique Gaul, nor were they bound up tight like Egyptian mummies. There is no evidence for "wrapped" burial or "bandelet-

29 I.e. been disunited.

30 Paulatim, if construed with consurgere, could mean that there will be various interim resurrections before the General Resurrection at End Time. But it might also be construed with docere: "you teach us gradually," implying an ongoing divine revelation (cf. Montanism).

31 P. Schierl, „Die motive «ewige Liebe» und «göttliche Belohnung» in der Wundererzählung der Laudes Domini," Motivi e forme della poesia cristiana antica tra Scrittura e Tradizione classica, XXXVI Incontro di studiosi dell 'antichità cristiana, Roma, 3-5 maggio 2007 (SEAug 108; Roma: Institutum Patristicum Augustinianum 2008) 861-871 discusses a range of parallel classical Gemeingut that is not actually meant to be source-material, but is thematically relevant: one grave, chastity of the survivor, praying to die simultaneously. I would add to the mix various Liebestode from Valerius Maximus 4.6, especially 4.6.3 the grave of the two lovers, Plautius and Orestilla.

32 A few secondary sources note that the author knew about Lazarus' resurrection in De Laudibus 118-119. E.g. G. Bardy, „Les Laudes Domini. Poème autunois du commencement du IVe siècle,” MASABLD (1933) 44. 
tes" in the West. Something else is going on. I'll betray the answer to this quite technical source-critical problem in advance. ${ }^{33}$

1. The rock tomb points to Judaea and can be compared to Jesus' grave. ${ }^{34}$

2. But the Carmen's narrative of a first (and temporary) Resurrection is imitating another famous narrative, one of a first and only a temporary Resurrection, ${ }^{35}$ namely that of Lazarus in the Gospel of John 11. The emphasis on the bandages is decisive. ${ }^{36}$

3. But the imitation is mediated by a contemporary Christian poet, Juvencus, who had paraphrased the Gospels in Latin hexameters. The author of the De Laudibus had Juvencus' version of Lazarus' Resurrection before him. ${ }^{37}$

The crucial problem the Gallic poet faced was turning Lazarus' uncanny and somewhat gruesome exhumation into a tender and reassuring love story. We can follow how he worked through the details of Lazarus' resurrection in Juvencus' paraphrase and how he adapted them.

\subsection{Liquefying Limbs and "Wrapped Burial:" From Smell to Bandages}

The grim realia of the grave included measures against the corpse's dissolution, such as mummification, embalming, shrouds, bandages. And smells were a problem. The Gospel is understandably terse about odors: 11.39 iam fetet: quadriduanus enim est, said Martha. Here Juvencus amplified:

'Quattuor en luces totidemque ex ordine noctes

Praetereunt, quo membra solo conposta quiescunt.

Crediderim, corpus motu fugiente caloris

Fetorem miserum liquefactis reddere membris. ${ }^{38}$

33 For a detailed treatment of these problems in the De Laudibus, see D. Shanzer, „Grave Matters: Love, Death, Resurrection, and Reception in the De laudibus Domini," Poésie, Bible et Théologie de l'Antiquité Tardive au Moyen Age (IV-XV sec) (ed. M. Cutino) (MilS; Berlin: De Gruyter) forthcoming.

34 Mt. 27.60 et posuit illud in monumento suo novo quod exciderat in petra et advolvit saxum magnum ad ostium monumenti et abiit. Also in Mc. 15.46.

35 Far less familiar is Mt. 27.52-53. For its questionable status, see Stuiber, Refrigerium interim, 11 and 34. See W.D. Davies - D.C. Allison, Matthew 19-28 (London: Bloomsbury 2004) 634 for various traditions about their eventual fate.

36 Joh. 11.44 Et statim prodiit qui fuerat mortuus ligatus pedes et manus institis et facies illius sudario erat ligata. Dicit Iesus eis, "Solvite eum et sinite abire!"

37 See Shanzer, „Grave Matters,” forthcoming.

38 Juvencus 4.376-79. 
Look, four days, and as many nights in succession have gone by during which his limbs have lain sleeping in the ground. I would imagine that, as its vivifying heat flees, his body is emitting a terrible stench from its liquefying limbs.

"Liquefying limbs," explains the smell. And the De Laudibus justifies its inappropriate grave-bandages as preventing informis fluitatio, "repulsive dissolution of limbs that are falling apart." ${ }^{39}$

\subsection{Bound Hand and Foot: "Dead Man Walking”}

Now a corpse in mummy-bindings was like a prisoner, bound hand and foot.

Haec cum dixisset voce magna clamavit, "Lazare, veni foras!" 44 Et statim prodiit qui fuerat mortuus ligatus pedes et manus institis et facies illius sudario erat ligata. Dicit Iesus eis, "Solvite eum et sinite abire!" (Joh. 11.43-44)

John here thematized Lazarus' "wrapped" mummy-like burial, and Jesus subsequently gave a command to release him. ${ }^{40}$ The Latin word used for Lazarus' locomotion is the colorless prodiit. One might well ask though: how did he walk with his feet bound together? Readers wondered about this too back in Late Antiquity. Some texts simply note the problem or declare it a miracle. ${ }^{41}$ But in the Eastern Empire a later Greek poet, Nonnos of Panopolis, staged a much spookier picture of the Lazarus' locomotion in a spectacularly creepy passage in his Gospel-Paraphrase:

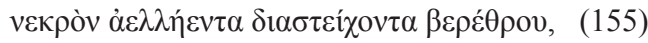

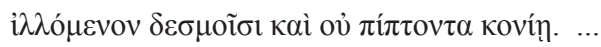

39 De laudibus 25 accidat informis fluitatio dissociatis. The emphasis on liquid decomposition comes from Juvencus.

40 Joh. 11.44 Solvite eum et sinite abire! And he is invariably depicted that way, see all the images in H. Leclercq - F. Cabrol, „Lazare,” DACL VIII/2, 2009-2088.

41 Like Ambrose of Milan's. We find one explicit reflection on the problem from the Western Empire in Ambrose's funeral oration for his brother Satyrus 78. Audivit ergo defunctus, et exivit foras de monumento, ligatus pedes et manus institis, et facies eius orario colligata erat. Conpraehende, si potes, quemadmodum clausis oculis iter carpat, vinctis pedibus gradum dirigat, inseparabili gressu, separabili progressu. Manebant vincula nec tenebant, tegebantur oculi, sed videbant. Videbat denique, qui resurgebat, qui ambulabat, qui deserebat sepulcrum. Virtute enim divinae praeceptionis operante natura suum non requirebat officium et tamquam in excessu posita non iam suo ordini, sed divino nutui serviebat. Rumpebantur prius mortis quam sepulturae vincula, agebatur prius, quam parabatur incessus. 79. Si miraris haec, disce, qui imperaverit, ut mirari desinas: Iesus Christus, dei virtus, via, lux, resurrectio mortuorum. 


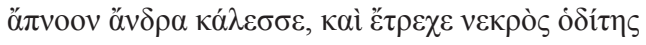

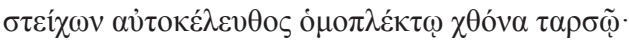

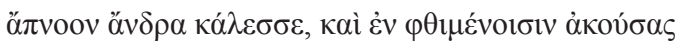

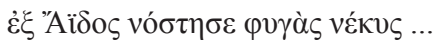

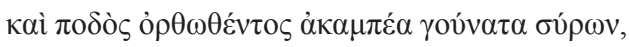

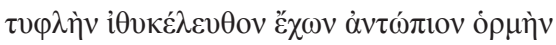

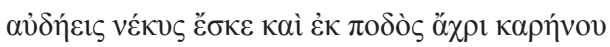

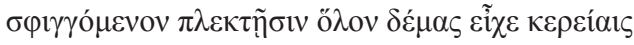

a wind-swift corpse, walking out of the pit, bound in chains/bonds, but not falling in the dust ..... he called an unbreathing man, and the dead traveler came running. Moving of his own accord on the ground with his ankles bound one to another. He called an unbreathing man, and the runaway corpse heard him among the dead and returned from Hades ... With upright foot, dragging his unbending knees, and maintaining a blind, eyes-front, straight path, he was a speaking corpse and, from foot to head, his whole body was bound with coils of [swaddling-]bands. ${ }^{42}$ [trans. DRS]

\subsection{Bound Hand and Foot: "Dead Lady Reaching"}

In the Carmen, however, hands are what matters. Our Gallic heroine, like une grande horizontale, plays the whole scene on her back. Her arms are bandaged tightly to her trunk. ${ }^{43}$ So the problem thus migrates north to her arms, and we hear how she can stretch out a hand, bound tightly though she was. ${ }^{44}$ This is a literary artifact, not an historical one. ${ }^{45}$ Here the miracle is that she can welcome and embrace.

42 Other translations in K. Spanoudakis (tr.), Nonnus of Panopolis. Paraphrasis of the Gospel of John XI (Oxford: Oxford University Press 2014) and into verse in M.A. Prost (tr.), Nonnos of Panopolis: The Paraphrase of the Gospel of John (Ventura, CA: The Writing Shop Press 2003).

43 This corresponds directly to Lazarus' grave-bindings, rendered by Juvencus 4.394-96 as conexis manibus pedibusque and et totum gracilis conectit fascia corpus.

44 Not actually "a conventional part of funerary practice” (as says R. Rees, „The Rhetoric and Poetics of Praise in the «Laudes Domini»," QUCC 95 [2010] 72).

45 A shroud ("linceul") is quite a different matter. I have benefitted from the help of Patrick Périn, Paul Van Ossel, and Bailey Young none of whom knew of any definite evidence for "wrapped burial," or "bandelettes," in the West. Van Ossel writes: "Je n'ai pas connaissance de sépultures tardives dont les corps seraient entourées de bandelettes à la manière d'une momie. J'ai souvent lu des attestations de découvertes de tissus dans les tombes (cela n'a vraiment rien d'original) mais un traitement du corps de type momification, cela ne me dit rien. Sachant qu'un tel rite devait être fort onéreux, il faudrait peut-être revoir les quelques tombes des élites connues pour leurs découvertes de tissus (linceul). Je pense effectivement à la tombe de Saint Paulin à Trèves, à celle de Naintré ou celle de Conthey dans le Valais. Il faudrait peut-être aussi vérifier la tombe double de Saint Victor à Xanten. Mais un linceul 


\subsection{The Plot Thickens...}

The first two main biblical resurrections were different from one another. Jesus' was a one-off event in Salvation history with no death to follow. ${ }^{46}$ Lazarus' was an act of compassion and power for Jesus' audience. ${ }^{47} \mathrm{He}$ is presumed to have lived out his lifespan before dying for real a second time. Whence came the Carmen's mini-Resurrection that lasted minutes at most?

\subsection{Tertullian}

There is a story in Tertullian that needs to be factored in:

Tertullian, De anima 51.6-8 Scio feminam quandam uernaculam ecclesiae, forma et aetate integra functam, post unicum et breue matrimonium cum in pace dormisset et morante adhuc sepultura interim oratione presbyteri componeretur, ad primum halitum orationis manus a lateribus dimotas in habitum supplicem conformasse rursumque condita pace situi suo reddidisse. Est et illa relatio apud nostros: in coemeterio corpus corpori iuxta collocando spatium accessui communicasse. Si et apud ethnicos tale quid traditur, ubique deus potestatis suae signa proponit, suis in solacium, extraneis in testimonium. Magis enim credam in testimonium ex deo factum quam ex ullis animae reliquiis, quae si inessent, alia quoque membra mouissent, et si manus tantum, sed non in causam orationis. Corpus etiam illud non modo fratri cessisset, uerum et alias mutatione situs sibimet ipsi refrigerasset. Certe undeunde sunt ista, signis potius et ostentis deputanda, naturam facere non possunt.

I know about a certain woman, a slave of the church, deceased when her looks were intact and she was still in her prime, after one short marriage. She had died peacefully and they had not yet buried her and she was being laid out in the meanwhile with a priest's prayer. At the first breath of prayer she arranged her limbs in the stance of a suppliant and moved her hands away from her sides and, when she had been laid to rest again after a kiss of peace, ${ }^{48}$ returned them to their place. This story is known among us [Christians] too, that a body made room for another body that was to be laid to rest beside it. ${ }^{49}$ If something of this sort is also handed down among the pagans, God proposes signs of his power everywhere, to console his own and to serve as testimony for outsiders. I would rather believe that this occurred as a sign from God than because of any remnants of soul, for if they were in the body, they would have moved other limbs too,

n'est pas une momie..." "To prevent dissolution" falls into the category of "too much information." The Gallic lady is "bouncing off" Lazarus, but Lazarus as recounted in Juvencus.

46 He rose up (German: auferstehen).

47 He was resurrected (German: auferweckt werden).

48 J.H. Waszink, Quinti Septimi Florentis Tertulliani De Anima (ed. J.D. Boeft) (SVC 100; Leiden Boston: Brill 2010) 532-533. But the expression is unparalleled.

49 For a much later reflection, see Greg. Mag. Dial. 3.23.1-4 below. 
and even if they moved the hands alone, it wouldn't have been for the sake of prayer. That body would not have made way for its brother alone but would have refreshed itself by changing its location and moving elsewhere. Wherever such things come from, there is no doubt that they are to be reckoned as signs and portents: they cannot constitute a natural event. ${ }^{50}$

Tertullian's story (better perhaps "urban legend") is related to, or itself, the source of the Carmen. But its function is quite different. It was used by others to show that some souls linger near certain corpses. ${ }^{51}$ For Tertullian it is a miracle. ${ }^{52}$ The lady is young, still beautiful, married, a church slave. Why must we be told this? Because Tertullian must emphasize that she is not one of the restless dead, not a murder-victim, nor a girl who died prematurely before her marriage.$^{53}$ Not a terrifying vampire. A good Christian, someone who prays with the priest at her own funeral. She thus has a philosophical function. But all of this is implicit.

A more casual reader could easily find the kernel of the story of the Carmen by combining the following narrative elements: 1. Faithful married woman. 2. Hands moved from the sides. 3. Body makes space for another body. 4. He also "tweaked" Tertullian to find a use for the hands other than prayer!

Thus, so far, the locomotion of the resurrected body and its sources in the Resurrection of Lazarus and that of Tertullian's pious slave. I'll now turn to how one got one's soul back, and where that image could lead.

\subsection{Getting One's Soul Back}

The Gospel doesn't explain how Jesus brought Lazarus back to life. ${ }^{54}$ But human embryos were ensouled, and death was the separation of soul from body. The pious commended their own souls at death ${ }^{55}$ or those of others at funerals. ${ }^{56} \mathrm{La}-$ zarus was re-ensouled. ${ }^{57}$ We need to envisage the handing over of an imagined soul. And that is exactly how Juvencus depicts Christ the Magician's gesture: ${ }^{58}$

50 Waszink, De Anima, 534 says natura = formam naturalem.

51 For the possible identity of these others as Stoics, see R. Turcan, „Origines et sens de l' inhumation à l'époque impériale," REA 60 (1958) 341-346.

52 The De laudibus is thus not the first allusion to a post-biblical miracle.

53 See S.I. Johnston, The Restless Dead (Berkeley: University of California Press 1999) especially chapters 4 and 5 .

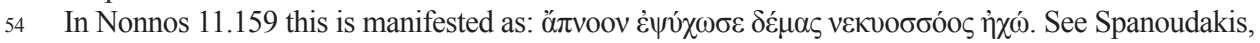
Nonnus of Panopolis, 275-278.

55 Lc. 23.46 et clamans voce magna Iesus ait Pater in manus tuas commendo spiritum meum et haec dicens exspiravit; also Phoenix 93: Tunc inter uarios animam commendat odores.

56 Suscipe animam servi tui illius et illius.

57 Cf. Prudentius, Cath. 9.48 reductus rursus intra halitus.

58 Why is Jesus depicted as giving Lazarus back his soul? Chromatius of Aquileia, Sermo $27.106 \mathrm{ff}$. is primarily concerned with the location of Lazarus' soul and how Jesus is able instantaneously to 
Juvencus 4. 392-93

'Lazare, sopitis redeuntem suscipe membris

En animam tuque ipse foras te prome sepulchro.

"Here, Lazarus! Take back your soul that now returns to your limbs that were sleeping, and you, bring yourself in person out from your sepulcher!" (In Christian art Jesus used a virga thaumaturgica. $)^{59}$ Juvencus reversed the usual formula for commending the spirit, which he envisaged as a winged creature. ${ }^{60}$ Now in Greco-Roman culture one's friend was half of one's soul ${ }^{61}$ and one's beloved was one's "soul" or "life." 62 If we take seriously the ambiguity in anima "soul" and also "beloved," then the Gallic lady is mysteriously re-ensouled when she welcomes back her beloved husband. Re-unification of body with body becomes life-giving because each lover was the other's soul. This conceit is worthy of an English metaphysical poet.

But what right does one have to imagine of endearments from the erotic sphere? Look at the diminutive lectulus ("little bed") and at that tell-tale word depren$s a$, which is standard for those caught in flagrante delicto. ${ }^{63}$ The anonymous poet wasn't lacking in urbanitas: his corpse was caught making a come-hither gesture! In Juvencus Jesus is the visible and audible thaumaturge within the story; in the Carmen he acts post mortem, invisibly and inaudibly, but is invoked by the rhetorical questions of De Laud. $32 \mathrm{ff}$.

\section{New Chastities: "Some, I think, do there embrace"}

I will now concentrate on one word in the Carmen, namely castis, as in "during these chaste times." The poet alludes to Christianity's radically innovative sexual and marital ethics. Its author envisages lifelong fidelity without remarriage after

reunite them. The reuniting is not just a decorative "point," but an allusion to an exegetic comparison between the re-ensoulment of Lazarus and God's ensoulment of the protoplast at Creation.

59 V. Tsamakda, „Eine ungewöhnliche Darstellung der Heilung des Paralytikers in der Domitilla-Katakombe: Zur Verwendung des Wunderstabes in der frühchristlichen Kunst," MiChA 15 (2009) 25-46.

60 The separation of the winged soul is mention at Juvencus 4.369-70 quo condita nuper/ Membra forent animae uolucris spoliata calore.

61 D.R. Shanzer, „Evodius' Strange Encounters with the Dead: Questions and Answers in Augustine, Epp. 158-159," Scrinium Augustini. The World of Augustine’s Letters (eds. P. Nehring - M. Stróżyński - R. Toczko) (Turnhout: Brepols 2017) 273-304.

62 Juvenal 6.194-95.

63 See for being caught "in fragrant delight," Hor. Sat. 1.2.131 cruribus haec metuat, doti deprensa, egomet mi and 134 deprendi miserum est. 
a real marriage: ${ }^{64}$ no "second Lady Curzon" here! But by the end of the $4^{\text {th }} \mathrm{C}$. yet another new Christian practice had emerged, namely "white marriage," living together as brother and sister from the start, or doing so subsequently, after a conversion. Hence bishops' wives (episcopae) ${ }^{65}$

And the Carmen's memorable story moved with the times-We find no fewer than four versions of it in $6^{\text {th }} \mathrm{C}$. Gaul in the works of Gregory of Tours. One version (GC 74) involves Rheticius of Autun who became a bishop after being widowed but had promised his wife privately that they'd rest in one grave. They couldn't move his bier when they tried to bury him separately. Fortunately, someone remembered the promise, and the corpse came back to life to commend himself to his wife. The sarcophagus shook, and his wife's bones were heaped up together ${ }^{66}$ in one place to make room for him. There is a fairly flat version in $G C$ 41 about a layman Hilarius of Dijon with an enormous Parian marble sarcophagus. He died first and embraced his wife when she joined him in the tomb a year later. This was a sign of fear of the Lord and chastity.

Did they or didn't they? Only God knows for sure...

The last two versions are both racier and wittier. One is in $D L H 1.47$. This is a lay-couple, "the lovers of Clermont," where the girl convinces her bride-groom on their wedding night in bed to have a sexless marriage. They shake hands on it in bed and slept together constantly thereafter in one bed. She died first, and, when he buried her, he said: "I give thanks, Jesus Christ, that I am returning to you the treasure that you commended to me just as stainless as when I received it." She woke up and smiled (subridens) and said, "Why are you mentioning what no one asked you?" ${ }^{67}$ Here there are two sarcophaguses side-by-side that move back together when displaced. One thinks of twin-beds in a hotel. The second

64 What sort of marriage was this? Some assume it was simply the faithful marriage of a (textbook epigraphic) univira, while others assume that the author intended a mariage blanc. To the best of my knowledge the question of perpetual marital continence is a later $4^{\text {th }} \mathrm{C}$. issue. For that reason, I am inclined to read De laudibus as about a normal marriage, where the two were both bedfellows and sexual partners. I strongly suspect that the phrase temporibus castis (De Laud. 21) may have been over-read, quite possibly in antiquity, and helped enable the back-reading of continence issues from the later $4^{\text {th }}$ to $6^{\text {th }} \mathrm{C}$. into the Constantinian period.

65 In the later $4^{\text {th }} \mathrm{C}$. people like Jerome were getting all hot and bothered about subintroductae and whether one tectulum implied one lectulum: As Jerome put it in the Ep. 117.9 separentur domus uestrae diuidaturque conuiuium, ne maledici homines sub uno tectulo uos manentes lectulum quoque criminentur habere communem. The battle about married bishops and episcopae was still being thrashed out in the $6^{\text {th }}$ C. For problems in Gregory, see D.R. Shanzer, „History, Romance, Love, and Sex in Gregory of Tours 'Decem Libri Historiarum', ' The World of Gregory of Tours (eds. K. Mitchell - I. Wood) (Leiden - Boston - Köln: Brill 2002) 395-418.

66 Ossa ... conglobantur is similar to Phoenix $116 \mathrm{ff}$. Ante tamen proprio quidquid de corpore restat / Ossaque uel cineres exuniasque suas / Unguine balsameo myrraque et ture soluto /Condit et in formam conglobat ore pio.

67 DHL 1.47 Nam cum, impleto certamine, puella migraret ad Christum peracto vir funeris officio cum puellam in sepulchro poneret, ait: 'Gratias tibi ago, domine Iesu Christe, aeternae domine deus 
version of this same story is in $G C$ 31, where the lay-pair later became a priest and a nun. Here again at her funeral the man gave thanks that he had given her back to God unpolluted by sexual pleasure. She awoke smiling to say, "Hush, Hush, man of God, there is no need for you to confess our secret, when no one is asking you!" 68 Furtive chastity is the secret, not, as customarily, furtive love.

\subsection{Unvarnished Horrors}

We have seen how a somber and frightening miracle is adapted to the taste of the theology of sentiment and given erotic and even playful coloring. But this sepulchral whitewash painted over what all knew perfectly well to be a gruesome reality, material for horror-films, the Uncanny. Gregory of Nyssa described the interment of his saintly sister Macrina in their parents' grave. This was a labor of love, for mother and daughter had asked to be laid to rest together, but the sight was a horror. ${ }^{69}$ For Gregory to behold his parents' decaying corpses would have been tantamount to "uncovering their nakedness." 70 A white linen sheet was interposed between the parents' and his sister's bodies. ${ }^{71}$

\subsection{Buried Alive with an Unwanted Partner}

Not only claustrophobes are terrified of being buried alive: Gregory of Tourswho else? - tells of righteous priest called — wait for it!-Anastasius, whose evil bishop locked him up alive in a huge Parian marble sarcophagus on top of an ancient dead body to torture him (DLH 4.12). Anastasius was subsequently to relate that a deadly stench emanated from the corpse. It was so strong that even though he covered his mouth and nostrils he still took it in through his ears! Fortunately,

noster, quia hunc thesaurum, sicut a te commendatum accepi, ita inmaculatum pietati tuae restituo'. Ad haec illa subridens: 'Quid', inquid, 'loqueris quod non interrogaris?'

68 GC 31 Cumque eam sepulchro reconderet, arcanum, quod inter eos convenerat, elevatis manibus ad caelum, pandit, dicens: "Gratias tibi, rerum omnium artifex, ago, quod, sicut mihi eam conmendare dignatus es, ita tibi reddidi ab omni voluptatis contagione inpollutam." "Sile, Sile, vir dei, quia non necesse est fatearis nostrum, nemine interrogante, secretum."

69 W. Jaeger - J.P. Cavarnos - V. Woods Callahan (eds.), Gregorii Nysseni Opera Ascetica (Gregorii

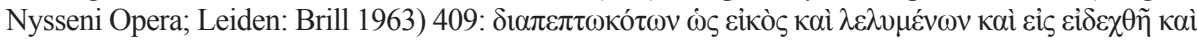

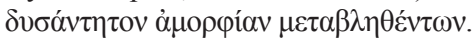

70 Jaeger - Cavarnos - Woods Callahan (eds.), Gregorii Nysseni, 409-410. Greg. Nyss., Vita Macrinae

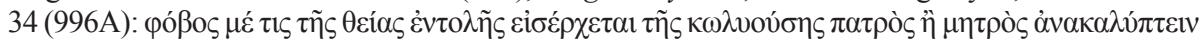

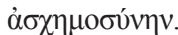

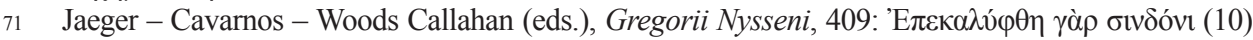

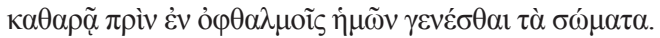


he could move his hands and found a crow-bar in the coffin that permitted him to lever off the top and escape, a new Jonah from the belly of the whale. ${ }^{72}$

\subsection{Men with Men}

To illustrate the versatility of this tale one has only to look at Gregory the Great's, Dial. 3.23 which relates what one might consider a monastic homosocial version. Even the humane Rule of Benedict sought to eliminate privacy from all aspects of the monastic life. Gregory's story needs to be read against the background of strictures such as $R B$ 22:

Quomodo dormiant monachi.

1 Singuli per singula lecta dormiant. 2 Lectisternia pro modo conuersationis secundum dispensationem abbae sui accipiant. 3 Si potest fieri, omnes in uno loco dormiant; sin autem multitudo non sinit, deni aut uiceni cum senioribus qui super eos solliciti sint pausent. 4 Candela iugiter in eadem cella ardeat usque mane. 5 Vestiti dormiant et cincti cingellis aut funibus, ut cultellos suos ad latus suum non habeant dum dormiunt, ne forte per somnum uulnerent dormientem; 6 et ut parati sint monachi semper et, facto signo absque mora surgentes, festinent inuicem se praeuenire ad opus Dei, cum omni tamen grauitate et modestia. 7 Adulescentiores fratres iuxta se non habeant lectos, sed permixti cum senioribus. 8 Surgentes uero ad opus Dei inuicem se moderate cohortentur propter somnulentorum excusationes.

The essentials include: one monk per bed, all together, or, at the very least, in a large dormitory with younger and older monks, a light burning at all times, all men dressed and belted. No younger monks to sleep next to other younger monks.

Gregory's point of departure is the relationship of an abbot and his protegé, a priest. There is a preliminary discussion about who will die first and whether there could possibly be room for two in one grave Here the two men end up in one (single) bed/grave, which ends up working out: the abbot's body turns on its

72 At presbiter, tamquam novus Ionas, velut de ventre inferi, ita de conclusione tumuli Domini misericordiam flagitabat. Et quia spatiosum, ut diximus, erat sarchofagum, etsi se integrum vertere non poterat, manus tamen in parte qua voluisset libere extendebat. Manabat enim ex ossibus mortui, ut ipse erat solitus referre, fetor letalis, qui non solum externa, verum etiam interna viscerum quatiebat. Cumque pallium aditus narium obseraret, quamdiu flatum continere poterat, nihil pessimum sentiebat; ubi autem se quasi suffocari potabat, remoto paululum ab ore pallio, non modo per os aut nares, verum etiam per ipsas, ut ita dicam, aures odorem pestiferum hauriebat. Quid plura? Quando Divinitati, ut credo, condoluit, manum dexteram ad spondam sarchofagi tendit, repperitque vectem, qui, decidente opertorio, inter ipsum ac labium sepulchri remanserat. Quem paulatim commovens, sensit, cooperante Dei adiutorio, lapidem amoveri. 
side to make room: Cumque fratres qui presbyteri corpus detulerant, factam sibi sepeliendi difficultatem viderent, unus eorum exclamavit, dicens: O Pater, ubi est quod dixisti, quia sepulcrum istud ambos vos ${ }^{73}$ caperet? Ad cuius vocem subito, cunctis videntibus abbatis corpus, quod illic ante positum fuerat, et supinum iacebat, sese vertit in latere, et vacantem sepulcri locum ad sepeliendum presbyteri corpus praebuit; et quia utrosque ille locus caperet, sicut vivus promiserat, mortuus implevit. This story is a distant descendant of Tertullian's urban legend about a corpse that made room for another corpse. ${ }^{74}$ But we can also hear a hint of the age-old lover's refrain, "I want to die first!" Gregory must have been aware of the erotic origins of the discourse in question, for the Erotic had long ago openly seeped into the homosocial world of the monks. ${ }^{75}$

\section{4 "Getting more than one bargained for"}

My final story is from the $7^{\text {th }}$ C. Byzantine East. Moschus, Pratum Spirituale 78 (620's/30's):

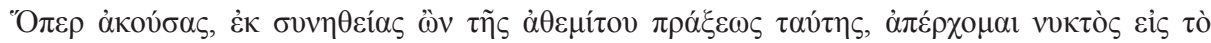

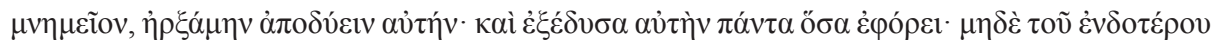

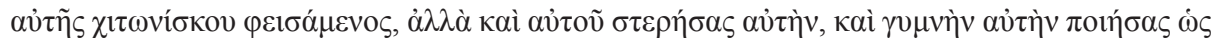

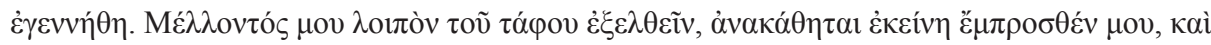

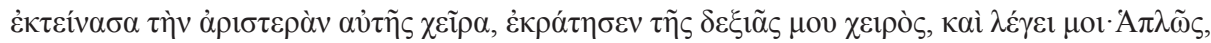

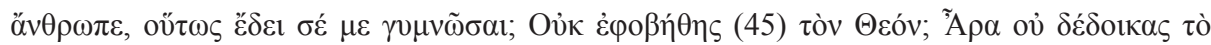

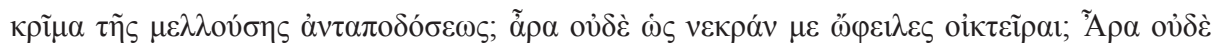

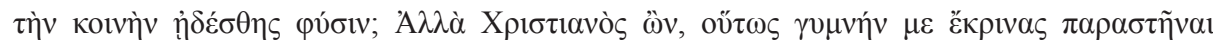

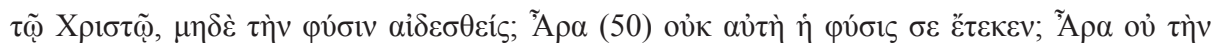

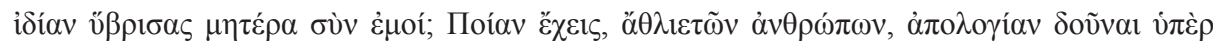

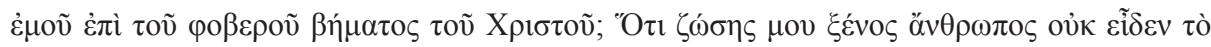

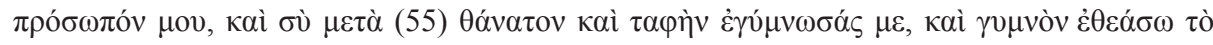

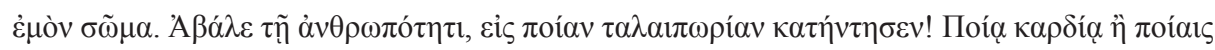

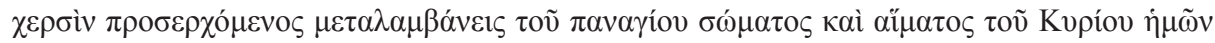

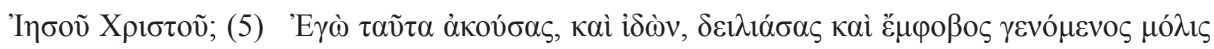

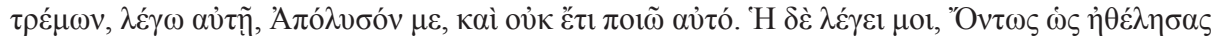

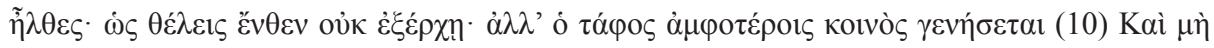

73 I emended to vos. Nos in PL 77.276D is probably a typo.

74 See above at 504-505.

75 See B.P. McGuire, Friendship and Community: The Monastic Experience, 350-1250 (Cistercian Studies Series 95; Kalamazoo, MI: Cistercian Publications 1988) 18 and S. Morris, When Brothers Dwell in Unity: Byzantine Christianity and Homosexuality (Jefferson, NC: Mcfarland 2016) 17-41, especially 22-33. 


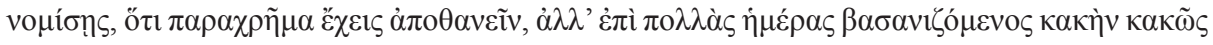

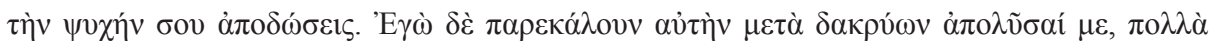

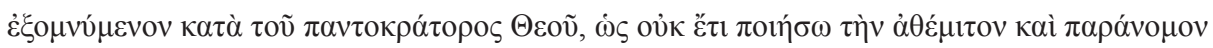

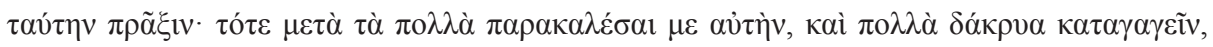

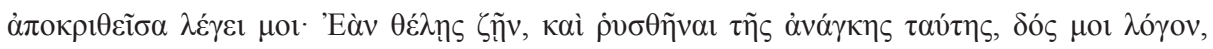

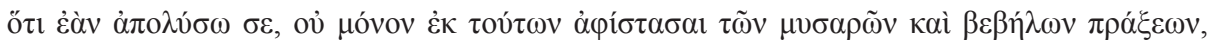

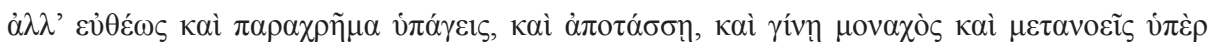

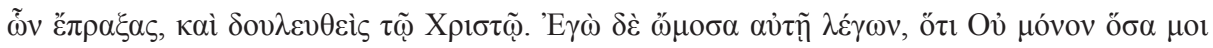

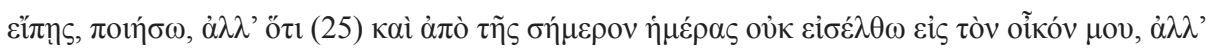

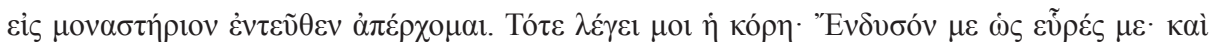

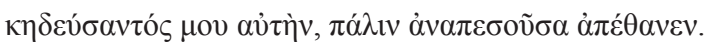

Hearing this (viz. that there was a newly buried rich virgin) and being accustomed to engage in this unlawful practice (sc. grave-robbing), I go at night into the tomb. I began to undress her and had stripped her of everything she was wearing. I didn't even spare her her inner shift, but took that off too, leaving her mother-naked. As I was about then to leave the tomb, she sat up near me and stretching out her left had seized my right one and said to me, 'So, O Man, you simply had to strip me like this? Didn't you fear God? Didn't you fear your sentence at the time of retribution to come? Shouldn't you have pitied me because I was dead? Didn't you fail to respect our common nature, and, even though you are a Christian, condemn me to arise [naked] before Christ, with no respect for my private parts. Didn't these genitals bear you? Aren't you violating your own mother in me? What sort of an excuse do you have to make for what you did to me, wretch among men, at Christ's terrifying tribunal? Even though when I was alive no stranger saw my face, you after my death and burial stripped me and beheld my body naked! Woe to humanity, to what depths has it descended! With what heart and what hands will you come forward to partake of the sacred blood and body of our Lord Jesus Christ?' Hearing this and seeing it, overcome by fear and cowardice, trembling, with difficulty, I say, 'Free me and I will never do it again!' She said to me, 'You certainly came here as you wished, but you will not come out as you wish; this will become a shared grave for both of us. Do not think that you will be able to die immediately. Tortured over many days, you will evilly surrender your evil spirit.' I begged her with tears to let me go, swearing many oaths by Almighty God that I would never again engage in this illegal and immoral practice. Then, after I had entreated her even more and shed many tears, she answered me, saying, 'If you wish to live and to be rescued from this dire strait, give me your promise that, if I release you, not only will you give up these abominable and unhallowed practices, but that you will forthwith instantly take your leave and withdraw and become a monk and repent for what you did by becoming servant of Christ." I swore to her, saying, 'Not only will I do everything you say, but also after the next day I will not reenter my house, but go away thence to a monastery.' Then the maiden said to me, 'Dress me as you found me.' And while I was attending to her, falling back, she died. [trans. DRS] 
It is a didactic miracle framed as the confession of a repentant tomb-robber to Abbot John and set in Antioch. The virgin daughter of a prominent family had been buried in many fine clothes. The tomb-robber entered the monument at night and stripped her down completely, not even leaving her shift. As he prepared to make his escape, the corpse sat up and seized him with her left hand by his right one. She rebuked him for not even sparing the modesty of her private parts, delivered a threatening sermon, and asked him how he would dare take communion. He panicked and begged to be released, promising to reform. She said: "Clearly you came as you wanted to, but you will not leave as you wish: this grave will be shared by both of us." He was to die a slow death, tortured there over many days. ${ }^{76} \mathrm{He}$ implored her. Finally, she took pity, but insisted he vow to stop his evil deeds and become a monk. And finally, "Dress me as you found me!" And when he had tended her, she fell back and died. John saw to it that the sinner eventually became a monk enclosed in a cave.

This is quite an unedifying pious little story ${ }^{77}$ with some similarity to a scene in an ancient Greek novel ${ }^{78}$ as well as a relationship to the Apocryphal Acts of John. ${ }^{79}$ The tomb-robber is threatened with live-entombment with a virginal female corpse that can sit up and move. It has clear erotic overtones: undressing her down to the shift, taking even that off, the virgin's genitals (physis), and her final request to be dressed again. This girl died before marriage and is a literary descendant of the amorous female revenant, Philinnion, who pursued a stranger. The shared grave is a terrifying threat, not a sentimental desideratum. And there is the perfect talio: the young monk ended his days locked up in a cave-alone.

76 For 2-3 ${ }^{\text {rd }}$ C. penalties (preserved in the Cod.Th.) for stripping a corpse see É. Rebillard, The Care of the Dead in Late Antiquity (Cornell Studies in Classical Philology 59; Ithaca, NY: Cornell University Press 2009) 63. See Valentinian III's novella (no. 23) of 447 in T. Mommsen et al., Theodosiani libri XVI : cum Constitutionibus Sirmondianis et Leges novellae ad Theodosianvm pertinentes (Berolini: apud Weidmannos 1905) II, 114-117 for harsher punishments including death, depending on social status.

77 Nicely to be compared with its predecessor in the collection Pratum Spirituale 77, which is a nonsexualized version in which the tomb-robber despoils a male corpse. And also a neat comparison to Petronius' Widow of Ephesus in Sat. 111-112. For legal and canonical treatments of abstract corpsestripping, see Rebillard, The Care of the Dead, 66-69 and 77 for Gregory of Nazianzus.

78 Compare Chariton, Chaereas and Callirhoe 1.6-9 for the heroine's Scheintod, entombment, (unintended) rescue, and eventual kidnapping by pirate tomb-robbers.

79 See Appendix below. 


\section{Conclusions}

It is a now famous cliché that Christians fostered a different relationship with the grave and its contents from that of their pagan confrères.$^{80}$ Issues of contamination, proximity, dismemberment, handling, and also horror and disgust needed to be rethought. We can use the Carmen and its kin, ${ }^{81}$ this strand of momentary resurrections in nuptial contexts, where two are interred in one grave, to observe and track developing Christian attitudes towards marriage, the grave, and the permeable border between life and death.

These stories about an odd phenomenon, namely, interim resurrection, started out as we see from Tertullian in a debate about the separation of the soul. Such not-so-dead bodies might understandably seem like vampires or zombies. Their intent might be frightening like Cynthia's threat to her lover Propertius soon to "grind bone on bone" with him in the grave.$^{82}$ Christians had to elbow aside such unwelcome connotations. They used John's story of Lazarus to "think with." 83

Matthew had mentioned mysterious appearances of the resurrected righteous dead in Jerusalem immediately after Jesus' death on the Cross, but left the outcomes hanging. ${ }^{84}$ What work are our later stories doing? First of all, they provided continuing revelation: proof in kind of Resurrection, a kind of toast for or taste of, ${ }^{85}$ or down-payment on, the final Resurrection. ${ }^{86}$ A cynic might note that they came cheap: one couldn't interview the momentarily resurrected. Secondly, the interim status of souls and their cognition were hotly disputed by theologians. ${ }^{87}$ One state known as "the sleep of the soul" aroused dismay and

80 Brown, The Cult of the Saints, 146-148.

81 Any Märchenforscher knows that these resemblances are not fortuitous.

82 Propertius, Carm. 4.7.93-94 mox sola tenebo; mecum eris, et mixtis ossibus ossa teram. This is a perversion of the sort of wish expressed by Hilara in $C E 1.365$, that her ashes eventually repose in her master's cinerary urn. Cynthia's threat can be compared to Sylvia Plath's 'Lady Lazarus' (in Ariel [1965] "Out of the ash/ I rise with my red hair /And I eat men like air."

83 Peter Chrysologus, Sermo 63 contrasts the resurrection of the daughter of Jairus and the son of the widow of Nain with that of Lazarus. In the first two cases the soul was lingering near the body and decomposition hadn't started. Lazarus had actually reached the underworld.

84 Mt. 27.52 et monumenta aperta sunt: et multa corpora sanctorum, qui dormierant, surrexerunt; 53 Et exeuntes de monumentis post resurrectionem ejus, venerunt in sanctam civitatem, et apparuerunt multis. On this mysterious passage, almost certainly a temporary resurrection, see Wright, The Resurrection, 632-636.

85 Petrus Chrysologus, Sermo 65 refers to it as a gustum resurrectionis Lazaro propinante.

86 Peter Chrysologus, Sermo 63 regards Lazarus' resurrection as a forma, exemplum, and figura of the conquest of death.

87 E.g. Quaestio 89. art. 8 of Thomas Aquinas, Summa, De Cognitione animae separatae: Octavo, utrum animae separatae a corporibus cognoscant ea quae hic aguntur; Petrus Lombardus, Sententiae 4.50.3.1. 
even distress in some. ${ }^{88}$ Thirdly, temporarily animated corpses unfortunately had a strong whiff of necromancy, especially if they involved a magician. ${ }^{89}$ So those connotations needed to be fended off. Our strand of stories both grants sentience to the corpses of the virtuous dead, and a connection between their souls and the world of the living that both comforts and exercises social control. However much Augustine would argue that the dead have no contact with the living and no concern about them, this was the theology of sentiment that would prevail in popular belief. ${ }^{90}$

\subsection{Afterward ... or Time after Time}

The Carmen's story was itself periodically resurrected during the Middle Ages. It attached itself to the Empress Kunigunde ( $\uparrow 1033)$ and her deceased consort Emperor Henry II (†1024), both eventually buried in Bamberg Cathedral in a tomb designed by Riemenschneider. In this case, the story carried Gregory of Tours' coloring, for there had been question-marks surrounding Kunigunde's childless marriage: was it a Josephsehe ${ }^{91}$ Was she chaste? She is said to have undergone the ordeal of the burning ploughshares. ${ }^{92}$ But a variant addition to her Vita, ${ }^{93}$ found in a 1484 edition from Brussels ${ }^{94}$ recounts how she was vindicated upon the re-interment of her body with Henry in Bamberg. She had, so it went, asked to be buried with him. When her body was deposited next to his, a voice rang out, "O virgo virgini locum tribue!"95 And, lo!, Henry's remains made space for Kunigunde's:

88 For the doctrine, see Aphraat, Ephrem, and Narsai, in F. Gavin, ,, The Sleep of the Soul in the Early Syriac Church,” JAOS 40 (1920) 103-120 and N. Constas, „An Apology for the Cult of the Saints in Late Antiquity: Eustratius of Constantinople, On the State of Souls after Death (CPG 7522)," JECS 10/2 (2002) 276. For the dismay, see Evodius in Shanzer, „Evodius' Strange Encounters with the Dead," 303.

89 E.g. Apuleius, Met. 2.28-29.

90 See I. Kajanto, ,The Hereafter in Ancient Christian Epigraphy,” Arctos 12 (1978) 32-33 for a perfect example of theologies competing in Paulinus of Nola's $C$. 31. Only martyrs' souls go straight to heaven, yet Paulinus suggests that young Celsus is already with the Holy Innocents up there.

91 H. Müller, Das heilige Kaiserpaar Heinrich und Kunigunde (Steyl: Missionsdrückerei 1905) 260-271.

92 Müller, Das heilige Kaiserpaar, 252-259. Also Baudouin de Gaiffier, „Intactam sponsam relinquens: À propos de la Vie de S. Alexis," AnBoll 65 (1947) 179.

93 The Vita Cunegundis was edited by Waitz in the MGH Scriptores (in folio) 6.4, pp. 821-824.

94 Socii Bollandiani (ed.), Bibliotheca Hagiographica Latina Antiquae et Mediae Aetatis (Bruxelles: Société des Bollandistes 1898-1899) I, 302 = BHL 2001.

95 VCunegundis 3 in AASS March 3, p. 276. de Gaiffier, „Intactam sponsam relinquens,” 179 dates the third book to the $13^{\text {th }} \mathrm{C}$. 
Ostendit autem Diuina potentia per euidens miraculum illic patratum, quam grata suscepta sit in caelis, quae sic supernis prodigijs honorabatur in terris. Denique, sicut ab incolis loci illius astantibus et praesentibus veridica assertione elatum est posteris; cum tumba S. Henrici aperiretur, vt corpus istius beatae virginis, uti in vita affectuose desiderarat, iuxta fratrem ac Dominum suum S. Henricum collocaretur; res plena miraculi ab omnibus praesentibus cernitur atque auditur. Siquidem aperto mausoleo, confestim vox desuper auditur, dicens: $\mathrm{O}$ virgo, virgini locum tribue. Mox ergo, cunctis qui aderant contuentibus, S. Henricus virgo dei electus, in monumento iacens, in alteram se partem mouit, et vxori suae, imo Christi virgini, locum praebuit. ${ }^{96}$

The story was also told of Abelard and Heloise by Pierre Bayle, ${ }^{97}$ who cited an unnamed Latin Chronicle from a manuscript of Tours. ${ }^{98}$

Lorsqu' il fut mort Moine de Clugni, elle demanda son corps à l'Abbé, \& l'aiant obtenu elle le fit enterer au Paraclet, \& voulut être enterrée dans le même tombeau. On conte un miracle des plus surprenans arrivé, dit-on, lorsque l'on ouvrit le sepulcre pour y mettre le corps d'Héloïse, c'est qu'Abélard lui tendit les bras pour la recevoir, \& qu'il l'embrassa étroitement. Il y avoit neanmoins plus de vingt bonnes années qu'il étoit mort; mais ce n'est pas une affaire; on pretend avoir des exemples de pareilles choses.

When he died as a monk at Cluny, she asked the Abbot for his body and, after she obtained it, had it buried at the Paraclete and wished herself to be buried in the same tomb. They tell of a miracle, a most surprising one, that happened, so they say, when they opened the sepulcher to bury Héloïse's body: namely that Abélard stretched out his arms to receive her and embraced her closely. But it had been nonetheless more than twenty years that he had been dead; One should not make a big deal of this: they claim to have examples of similar events.

The work in question must be Guillaume de Nangis' Chronicle s.a. $1140,{ }^{99}$ which relates the legend thus:

Quae vere ipsius amica, magnam ei post mortem in assiduis precibus fidem servavit.

Corpusque ejus de loco ubi obierat transtulit ad praedictum coenobium Paracliti; in cujus tumulo hoc epitaphium est insertum:

Est satis in titulo: Petrus hic jacet Abaelardus

Cui soli patuit scibile quidquid erat.

96 J.P. Toussaint, Geschichte der heiligen Kunigunde von Luxemburg, Kaiserin von Deutschland (Paderborn: Bonifacius-Druckerei 1901) 109-110.

97 P. Bayle, Dictionnaire Historique et Critique (Rotterdam: Reinier Leers, 1697) II/1, 47-48.

98 Bayle, Dictionnaire Historique et Critique, II/1, 48.

99 J.F. Venette - H. Géraud (eds.), Chronique latine de Guillaume de Nangis de 1113 à 1300: avec les continuations de cette chronique de 1300 à 1368 (Paris: Renouard 1843) 33. 
(i) Haec namque, sicut dicitur, in aegritudine ultima posita, praecepit ut mortua infra mariti tumulum poneretur . Et sic eadem defuncta ad tumulum apertum deportata, maritus ejus, qui multis diebus ante eam defunctus fuerat, elevatis brachiis, illam recepit, et ita eam amplexatus, brachia sua strinxit.

Since she was truly his beloved, she kept her great loyalty to him in her constant prayers. She transferred his body from the place where had died to the afore-mentioned Abbey of the Paraclete. On his tomb was added this epitaph:

All is said in this inscription: Here lies Peter Abelard

To whom alone everything that could be known lay revealed.

For she, as they say, when on her deathbed, gave orders that when she died she be placed in the tomb of her husband. And thus when she died and had been carried to the open grave, her husband, who had died many days before her, raised his arms, took her in them, and thus having embraced her, tightened his arms closely around her.

The exceptionally learned Bayle knew of the earlier parallels in Gregory and cynically alluded to them with his "on pretend." 100 Hughes in the $18^{\text {th }} \mathrm{C}$., working from Bayle, struck an even more enlightened note:

However, a manuscript of Tours gives us an account of an extraordinary miracle which happened when Abelard's grave was opened for Heloise's body, namely that Abelard stretched out his arms to receive her, and embraced her closely, though there were twenty good years passed since he died. But that is a small matter to a writer of miracles. ${ }^{101}$

It took Lord Byron to recast Bayle's account in poetically passionate form in 1823 in a radically different context, transported to the South Seas:

Not mine to tell the rapturous caress

Which followed wildly in that wild recess

This tale; enough that all within that cave

Was love, though buried strong as in the grave

Where Abelard, through twenty years of death,

When Eloisa's form was lowered beneath

Their nuptial vault, his arms outstretched and prest

The kindling ashes to his kindled breast. ${ }^{102}$

100 Bayle, Dictionnaire Historique et Critique, II/1, 48.

101 J. Hughes, Letters of Abelard and Heloise: With a Particular Account of Their Lives, Amours, and Misfortunes (London: Pridden 1780) 77-78.

102 George Gordon, Lord Byron, The Island, Canto 4. 219-26 


\section{Appendix: the Apocryphal Acts of John}

Pratum Spirituale 78 can be instructively compared to the story of Callimachus and Drusiana, which forms part of the Apocryphal Acts of John $(A J)$ and is transmitted both in Greek ${ }^{103}$ and in Latin. ${ }^{104}$ The narrative, set in Ephesus, is explicitly about necrophilia. Drusiana, a matron of Ephesus, is in a virginal marriage to Andronicus, whom she has converted to her ascetic ways. One Callimachus falls in love with her, which so upsets her that she herself dies of despair at the effect of her beauty. The love-mad Callimachus bribes Andronicus' evil overseer Fortunatus to obtain access to her tomb. While the two are stripping the body down to its shift ( $A J$ 70-71), apparently for a necrophiliac threesome, they are struck down by a serpent, sent by God. John and Andronicus come to the tomb to witness the extraordinary scene. Eventually all three protagonists are revived (Callimachus) or resurrected (Drusiana and Fortunatus) to be offered a chance of repentance. Fortunatus alone persists in his envious wickedness. The trappings of the story are derived from the events at Jesus Tomb. Drusiana's corpse is protected from a fate worse than death. Even though this story's outer layer openly admits the sexual subplot, in the end it is considerably cleaner than the scene in Moschus, which, though preaching decency, cannot be described as other than kinky. The resurrected Drusiana finds it in her heart to forgive herself her would-be rapist ( $A J$ 83). We do not have sufficient information to explain the relationship between Moschus and the $A J$, but incoherent details (Überbleibsel) in the $\mathrm{AJ}$, such as the information that Andronicus had immured Drusiana in a tomb to convince her to have sex with him point to a wider (now lost) tradition. ${ }^{105}$ In the $11^{\text {th }} \mathrm{C}$. Hrotsvitha of Gandersheim would use the Latin $V J$ as the basis of her drama the Calimachus. ${ }^{106}$

\section{Bibliography}

103 AJ 58-86 in J.-D. Kaestli - E. Junod (eds.), Acta Iohannis (CCSA 1; Turnhout: Brepols 1983) I, 242-292 for the Greek with a French translation.

104 Virtutes Johannis 4 (VJ) in Kaestli - Junod (eds.), Acta Iohannis, I, 803-814 with a French translation.

105 AJ63 in Kaestli - Junod (eds.), Acta Iohannis, 252-253. Jan N. Bremmer, ,Women in the Apocryphal Acts of John," The Apocryphal Acts of John (ed. J.N. Bremmer) (SAAA 1; Kampen: Kok Pharos 1995) 42 notes that a tradition from the Manichaean Coptic Psalter attests that she was locked up with John.

106 See H. Homeyer, Hrotsvithae Opera. Mit Einleitung und Kommentar (München - Paderborn - Wien: Schöningh 1970) and W. Berschin (ed.), Hrotsvit: Opera Omnia, Bibliotheca Scriptorum Graecorum et Romanorum Teubneriana (Monachii - Lipsiae: Sauer 2001). 
Bardy, G., „Les Laudes Domini. Poème autunois du commencement du IVe siècle,” Mémoires de l'Académie des Sciences, Arts et Belles-lettres de Dijon (1933) 36-51.

Bayle, P., Dictionnaire Historique et Critique (Rotterdam: Reinier Leers 1697) II/1.

Berschin, W. (ed.), Hrotsvit: Opera Omnia, Bibliotheca Scriptorum Graecorum et Romanorum Teubneriana (Monachii - Lipsiae: Sauer 2001).

Socii Bollandiani (ed.), Bibliotheca Hagiographica Latina Antiquae et Mediae Aetatis (Bruxelles: Société des Bollandistes 1898-99) I.

Bowersock, G.W., Fiction as History: Nero to Julian (Berkeley, CA - Los Angeles, CA - London: University of California Press 1994).

Brandenburg, H., „Der Beginn der stadtrömischen Sarkophagproduktion der Kaiserzeit.” Jahrbuch des deutschen archäologischen Instituts 93 (1978) 277-327.

Brandes, W., Über das frühchristliche Gedicht »Laudes Domini«: Nebst einem Excurse: Die Zerstörung von Autun unter Claudius II (Braunschweig: Meyer 1887).

Brelich, A., Aspetti della morte nelle iscrizioni sepolcrali dell'impero romano (Dissertationes Pannonicae 1/7; Budapest: Istituto di Numismatica e di Archeologia dell' Università Pietro Pázmány 1937).

Bremmer, J.N., „From Heroes to Saints and from Martyrological to Hagiographical Discourse,” Sakralität und Heldentum (eds. F. Heinzer - J. Leonhard - R. von den Hoff) (Würzburg: Ergon 2017) 35-66.

Bremmer, J.N., ,Women in the Apocryphal Acts of John,” The Apocryphal Acts of John (ed. J.N. Bremmer) ( Studies on the Apocryphal Acts of the Apostles 1; Kampen: Kok Pharos 1995) 37-56.

Brown, P., The Cult of the Saints: Its Rise and Function in Latin Christianity (Chicago: University of Chicago Press 1981).

H. Leclercq - Cabrol, F., „Lazare,” Dictionnaire d'archéologie chrétienne et de liturgie (eds. F. Cabrol - H. Leclercq) (Paris: Letouzey et Ané 1929) VIII/2, 2009-2088.

Constas, N., „An Apology for the Cult of the Saints in Late Antiquity: Eustratius of Constantinople, On the State of Souls after Death (CPG 7522)," Journal of Early Christian Studies 10/2 (2002) 267-285.

Corbier, M., „Constructing Kinship in Rome: Marriage and Divorce, Filiation and Adoption,” The Family in Italy: from Antiquity to the Present (eds. D.I. Kertzer - R.P. Saller) (New Haven, CT: Yale University Press 1991) 127-144.

Davies, W.D. - Allison, D.C., Matthew 19-28 (London: Bloomsbury 2004).

de Gaiffier, B., „Intactam sponsam relinquens: À propos de la Vie de S. Alexis,” Analecta Bollandiana 65 (1947) 157-195.

Diehl, E., Inscriptiones latinae christianae veteres (Berlin: Weidmann 1925-1927) I-II.

Doroszewska, J., The Monstrous World: Corporeal Discourses in Phlegon of Tralles' Mirabilia (Warsaw Studies in Classical Literature and Culture 4; Frankfurt am Main: Peter Lang 2016).

Graham E.-J., „Corporeal Concerns: The Role of the Body in the Transformation of Roman Mortuary Practices," Death Embodied Archaeological Approaches to the Treatment of the Corpse (eds. Z.L. Devlin - E.-J. Graham) (Studies in Funerary Archaeology 9; Havertown, PA: Oxbow Books 2015) 28-38.

Gavin, F., „The Sleep of the Soul in the Early Syriac Church,” Journal of the American Oriental Society 40 (1920) 103-120. 
Hassauer, F., Santiago: Schrift, Körper, Raum, Reise. Eine medienhistorische Rekonstruktion (München: Fink 1993).

Haynes, S., Etruscan Civilization: A Cultural History (Los Angeles, CA: J. Paul Getty Museum 2000). Homeyer, H., Hrotsvithae Opera. Mit Einleitung und Kommentar (München - Paderborn - Wien: Schöningh 1970).

Hopkins, K., Death and Renewal: Sociological Studies in Roman History (Cambridge: Cambridge University Press 1983) II.

Hughes, J., Letters of Abelard and Heloise: With a Particular Account of Their Lives, Amours, and Misfortunes (London: Pridden 1780).

Jaeger, W. - Cavarnos, J.P. - Woods Callahan, V. (eds.), Gregorii Nysseni Opera Ascetica. (Gregorii Nysseni Opera; Leiden: Brill 1963).

Johnston, S.I., The Restless Dead (Berkeley: University of California Press 1999).

Kaestli, J.-D., - Junod, E. (eds.), Acta Iohannis (Corpus Christianorum, Series Apocryphorum 1-2; Turnhout: Brepols 1983) I-II.

Kajanto, I., „The Hereafter in Ancient Christian Epigraphy,” Arctos 12 (1978) 27-53.

Kötting, B., Peregrinatio religiosa: Wallfahrten in der Antike und das Pilgerwesen in der alten Kirche (Münster: Regensberg 1950).

Le Blant, E.F., Inscriptions chrétiennes de la Gaule antérieures au VIIIe siècle (Paris: L'Imprimerie Impériale 1856) II.

MacMullen, R., Christianity and Paganism in the Fourth to Eighth Centuries (New Haven, CT London: Yale University Press 1997).

MacMullen, R., „The End of Ancestor Worship: Affect and Class,” Historia 63 (2014) 487-513.

MacMullen, R., Paganism in the Roman Empire (New Haven, CT - London: Yale University Press 1981).

MacMullen, R., „Roman Religion: The Best Attested Practice,” Historia 66/1 (2017) 111-127.

McGuire, B.P. Friendship and Community: the Monastic Experience, 350-1250 (Cistercian Studies Series 95; Kalamazoo, MI: Cistercian Publications 1988).

Mommsen, T. et al., Theodosiani libri XVI: cum Constitutionibus Sirmondianis et Leges novellae ad Theodosianvm pertinentes (Berolini: apud Weidmannos 1905) II.

Morris, S., When Brothers Dwell in Unity: Byzantine Christianity and Homosexuality (Jefferson, NC: Mcfarland 2016).

Mosley, L.O., Curzon: The End of an Epoch (London: Longmans 1960).

Müller, H., Das heilige Kaiserpaar Heinrich und Kunigunde (Steyl: Missionsdrückerei 1905).

Nock, A.D., „Cremation and Burial in the Roman Empire,” Harvard Theological Review 25/4 (1932) 321-359.

Opelt, I. „Das Carmen de laudibus Domini als Zeugnis des Christentums bei den Galliern,” Romanobarbarica 3 (1978) 159-166.Prost, M.A. (tr.), Nonnos of Panopolis: The Paraphrase of the Gospel of John (Ventura, CA: The Writing Shop Press 2003).

Rebillard, É., The Care of the Dead in Late Antiquity (Cornell Studies in Classical Philology 59; Ithaca, NY: Cornell University Press 2009).

Rees, R., „The Rhetoric and Poetics of Praise in the «Laudes Domini»," Quaderni Urbinati di Cultura Classica 95 (2010) 71-84.

Salzano, A., Laudes Domini: Introduzione, testo, traduzione e commento (Quaderni del Dipartimento di Scienze dell'Antichità, Università degli Studi di Salerno 23; Napoli: Arte Tipografica 2000). 
Sandys, J.E., Latin Epigraphy: An Introduction to the Study of Latin Inscriptions (Cambridge: Cambridge University Press 1919).

Schierl, P. „Die motive «ewige Liebe» und «göttliche Belohnung» in der Wundererzählung der Laudes Domini," Motivi e forme della poesia cristiana antica tra Scrittura e Tradizione classica, XXXVI Incontro di studiosi dell'antichità cristiana, Roma, 3-5 maggio 2007 (Studia Ephemeridis Augustinianum 108; Roma: Institutum Patristicum Augustinianum 2008) 861-871.

Shanzer, D.R., „Grave Matters: Love, Death, Resurrection, and Reception in the De laudibus Domini," Poésie, Bible et Théologie de l'Antiquité Tardive au Moyen Age (IV-XV sec) (ed. M. Cutino) (MilS; Berlin: De Gruyter) forthcoming.

Shanzer, D.R., „Evodius' Strange Encounters with the Dead: Questions and Answers in Augustine, Epp. 158-159," Scrinium Augustini. The World of Augustine's Letters (eds. P. Nehring M. Stróżyński - R. Toczko) (Turnhout: Brepols 2017) 273-304

Shanzer, D.R., „History, Romance, Love, and Sex in Gregory of Tours 'Decem Libri Historiarum,,' The World of Gregory of Tours (eds. K. Mitchell - I. Wood) (Leiden - Boston - Köln: Brill 2002)

Spanoudakis, K. (tr.), Nonnus of Panopolis. Paraphrasis of the Gospel of John XI (Oxford: Oxford University Press 2014).

Stuiber, A., Refrigerium interim. Die Vorstellungen vom Zwischenzustand und die frühchristliche Grabeskunst. XI. Theophaneia (Bonn: Hanstein 1957).

Toussaint, J.P., Geschichte der heiligen Kunigunde von Luxemburg, Kaiserin von Deutschland (Paderborn: Bonifacius-Druckerei 1901).

Tsamakda, V., „Eine ungewöhnliche Darstellung der Heilung des Paralytikers in der Domitilla-Katakombe: Zur Verwendung des Wunderstabes in der frühchristlichen Kunst," Mitteilungen zur Christlichen Archäologie 15 (2009) 25-46.

Turcan, R., „Origines et sens de l' inhumation à l'époque impériale,” Revue des Études Anciennes 60 (1958) 323-347.

Venette, J.F. - Géraud H. (eds.), Chronique latine de Guillaume de Nangis de 1113 à 1300: avec les continuations de cette chronique de 1300 à 1368 (Paris: Renouard 1843.

Waszink, J.H., Quinti Septimi Florentis Tertulliani De Anima (ed. J.D. Boeft) (Supplements to Vigiliae Christianae 100; Leiden - Boston: Brill 2010).

Wright, N.T., The Resurrection of the Son of God (Minneapolis, MN: Fortress Press 2003).

Zellentin, H.M., Rabbinic Parodies of Jewish and Christian Literature (Texts and Studies in Ancient Judaism 139; Tübingen: Mohr Siebeck 2011). 